\title{
LIFO Distortion in the Oil Industry - Revisited
}

\author{
June $\operatorname{Li}^{1} \&$ Megan Y. Sun ${ }^{1}$ \\ ${ }^{1}$ College of Business and Economics, University of Wisconsin at River Falls, Wisconsin, USA \\ Correspondence: June Li, College of Business and Economics, University of Wisconsin, River Falls, WI 54022, \\ USA. Tel: 715-425-3335
}

Received: June 25, 2017

Accepted: July 23, 2017

Online Published: August 1, 2017

doi:10.5430/afr.v6n3p56

URL: https://doi.org/10.5430/afr.v6n3p56

\begin{abstract}
LIFO (Last in First out) inventory method has been widely used by US publicly traded companies for its tax advantages in many years. However, LIFO is expected to be repealed with the impending acceptance of IFRS (the International Financial Reporting Standards) by the SEC. The repeal of LIFO will significantly increase the tax liabilities of those companies previously using LIFO. One hardest hit industry by repeal of LIFO is oil industry. Our study investigates the use of LIFO inventory method in oil industry from 2008 through 2015 . The primary focus of this study is the accounting information distortion as a result of using LIFO. We document severe accounting information distortion in the areas of working capital and inventory turnover. Though not as severe, we also observe very significant distortions in the areas of gross profit and current ratio. The accounting information gets increasingly distorted from 2008 to 2011. However the trend reverses from 2012 to 2015. Each of the Obama administration's budgets proposals proposed the elimination of LIFO for inventories. We believe the findings of our research have significant implications for the policy makers. In addition, a full adoption of IFRS, which prohibits LIFO, is unlikely in the near future. Non-public companies who are not under the jurisdiction of the SEC may still continue to use LIFO after the adoption of IFRS.
\end{abstract}

Keywords: LIFO, Oil Industry, IFRS

\section{Introduction}

Last in First out (LIFO) inventory method assumes that the company sells the inventory most recently acquired or manufactured first. Therefore, LIFO allows matching current income with the most recent higher cost of inventory. In an inflationary period, LIFO inventory method produces the highest amount of cost of goods sold and lowest amount of inventory, which leads to the lowest taxable income and the highest tax savings. Industries that often experience rising inventory costs typically use LIFO as the inventory accounting method, which enables businesses to avoid phantom profits caused by inflation.

Internal Revenue Code section 472 allows a company to use the LIFO for tax purposes if it also uses LIFO for financial reporting purposes (the "conformity rule"). This rule has resulted in tremendous tax savings for LIFO users. As a results, LIFO has been targeted by lawmakers as a way to increase tax revenue. For instance, each of the Obama administration's budgets proposals proposed the elimination of LIFO for inventories (Pomerleau 2016). The elimination of LIFO for inventories will require US publicly traded companies that currently use LIFO to adopt first-in-first-out (FIFO) or average-cost as permitted under the International Financial Reporting Standards (IFRS). The repeal of LIFO will significantly increase tax liabilities for these companies and increase tax revenue for the government. According to Lundeen (2015), the repeal of LIFO is projected to increase tax revenues by 1.7 trillion over ten years.

The hardest hit industries by the repeal of LIFO documented by numerous studies are the oil and manufacturing industries (e.g. Leone 2010). A lot of research has been conducted on the LIFO use in oil and manufacturing industry (e.g. Li and Sun 2014, Lirely, Coffee, Roig, and Swanger 2010). Li and Sun (2014) find significant income and liquidity distortions in inventory turnover, gross profit, working capital and current ratio in the oil industry from 2008 through 2012. There is also strong evidence that LIFO leads to significant distortions in the same accounting measures in the manufacturing industry from 2008 through 2014 ( $\mathrm{Li}$ and Sun 2016). However, while remaining significant, the distortions start to decrease after 2011 for the manufacturing industry. In anticipation of the adoption of IFRS under which LIFO is prohibited, the manufacturing industry appears to have gradually changed their inventory method away from LIFO. With the decline in oil prices in recent years, this study provides a follow up for 
the LIFO accounting distortion in the oil industry. Our results will provide evidence whether the oil industry, similar to their manufacturing counterparts, has gradually switched away from LIFO inventory method.

Our study is arranged as follows. In section 2, we present prior research. In section 3, we discuss data and methodology. In section 4, we provide empirical results. We conclude the paper with discussion in section 5 and a summary of evidence in section 6 .

\section{Prior Research}

In a period of inflation, the accounting value of the inventory under LIFO is lower than its current market value. Therefore the inventory values on the balance sheet under LIFO is grossly understated, while highest cost of goods and lowest tax liability are reported on the income statement. By distorting the balance sheet, LIFO creates an enhanced income statement for its users. As a result, the SEC requires all publicly traded companies to report LIFO reserve since 1972. LIFO reserve is calculated as the excess of current cost (or replacement cost) of inventory over LIFO inventory stated on the balance sheet. LIFO reserve not only represents the cumulative inventory value differential between LIFO and an alternative inventory valuation method, but also represents the cumulative income differential that a company could have reported over the time period while it is on LIFO.

\subsection{LIFO Reserve \& Accounting Distortions}

Due to its profound implication of LIFO reserve on the balance sheet and income statement, LIFO reserve has been widely studied in accounting research in recent years (for example, Kostolansky and Polnaszek 2013, Reineking, Chamberlain, Rudolph, and Smith 2013, Jacob and Zhang 2014, Harris and Stahlin 2014, Harris, Stahlin and Shubita 2014, Houmes and Chira 2015). Accounting research finds that during increasing inventory prices LIFO reserve could be very substantial when compared to the reported inventory. Reeve and Stange (1987) find that there is a positive relationship between LIFO reserve and the years a company has been using LIFO. They document that the LIFO reserve is averaged at about $38 \%$ of the reported LIFO inventory on 56 selected companies. More recently, Kostolansky (2009) provide evidence on how widely used LIFO is. He reports that out of the Fortune 500 companies, 38 percent of the firms use LIFO method to report inventory. He finds significant differences in the reported value of inventory and net income for those LIFO users.

Accounting distortion created by LIFO is another heated topic. Using data from the years of 2007 and including 355 active publicly traded US companies from many different industries with a positive LIFO reserve, Coffee, Roig, Lirely, and Little (2009) study the accounting distortions on liquidity measures created by the use of LIFO inventory valuation method. They find significant balance sheet distortions in areas of inventory turnover, current ratio, and working capital across different company sizes and different industries.

\subsection{LIFO \& Oil Industry}

Lirely, Coffee, Roig, and Swanger (2010) document a material LIFO impact for some of the LIFO users. They provide evidence that LIFO inventory valuation method produces material accounting distortions for energy companies both in absolute dollar amounts and in amounts relative to other assets and liabilities. Their research documents that a greater distortion is observed in the energy industry, followed by the manufacturing industry, than that in other industries. Their research shows that energy industry might benefit most from using LIFO inventory valuation method. More recently, Hughes \& Nucci (2015) document the oil companies have been reducing their inventory levels over the past few years due to a massive drop in oil prices. They argue for the elimination of LIFO for U.S. financial reporting.

In addition, using data between 2008 through 2012 from 14 major oil companies, Li and Sun (2014) provide evidence that the use of the LIFO inventory accounting method by oil companies results in significant accounting information distortions in many accounting measures. They find greatest accounting distortion in working capital, followed by the inventory turnover ratio, the gross profit and the current ratio. LIFO impact on the energy industry has been documented in other researches too (e.g. Guenther and Sansing 2012, Coffee, Roig, Lirely, and Little 2009, Moreland 2007, Lessard 2007).

The LIFO usage in other industry has also been investigated. Murdoch, Dehning and Krause (2013) find that the LIFO earnings is superior to FIFO earnings for predicting operating cash flows especially for the manufacturing and services industries among the 10 industries examined. Research on the impact of LIFO on the manufacturing industry is limited. However, Li and Sun (2016) find strong evidence that LIFO leads to significant accounting distortions in the manufacturing industry from 2008 through 2014. Interestingly, the accounting distortions start to decrease after 2011 for the manufacturing industry. According to their research, the manufacturing industry have gradually switched their inventory method away from LIFO in anticipation of the repeal of LIFO. The largest LIFO 
accounting distortions are observed the oil and the manufacturing industries. There has been no recent studies on the oil industry and LIFO distortion. Our study investigates if the same trend can be observed in the oil industry. We believe the findings will have significant implications for policy makers.

\section{Methodology}

Similar methodology for liquidity measurements on LIFO has been used in published studies (Coffee et al. 2009, Lirely et al. 2010, Li and Sun 2014, 2016). We acquired data from Compustat/ Research Insight North American database (2016). We limit our sample to U.S. companies with a positive LIFO reserve and complete data for analysis. Excluding firms with incomplete data, we identified 12 major oil companies which are LIFO users. Relevant data spanning from January 2008 to December 2015 are obtained for all these companies.

The companies are examined to identify the level of accounting distortions resulting from the use of LIFO. Specifically, we compare inventory turnover, working capital, gross profit, and current ratio constructed using the data as reported in the financial statement with the same adjusted measures constructed using reported data adjusting for the amount of LIFO reserve. These adjusted measures are constructed using the following adjusted data:

Year-end Adjusted Inventory $=$ Year-end Reported Inventory + LIFO reserve

Beginning Adjusted inventory = Beginning Reported Inventory + LIFO reserve from previous year

Average Adjusted Inventory $=($ Year-end Adjusted Inventory + Beginning Adjusted inventory $) / 2$

Adjusted Inventory Turnover Ratio $=($ Cost of Goods sold - LIFO reserve $) /$ Average adjusted inventory

Adjusted Gross Profit $=$ Sales - Adjusted Cost of Goods Sold

Adjusted Working Capital $=$ Reported Working Capital + LIFO reserve

Adjusted Current Ratio $=($ Reported Current Asserts +LIFO Reserve $) /$ Reported Current Liability

The accounting distortion in inventory turnover ratio is the percentage difference between the adjusted inventory turnover ratio and reported inventory turnover ratio, while the accounting distortion in gross profit is the percentage difference between the adjusted gross profit and the reported gross profit. Similarly, we measure the accounting distortion in working capital as the percentage difference between the adjusted working capital and reported working capital, while the accounting distortion in current ratio is the percentage difference between adjusted current ratio and reported current ratio.

\section{Empirical Results}

In an inflationary period, LIFO assigns the most recent prices to cost of goods sold and oldest prices to remaining inventory. This results in the highest cost of goods sold, lowest taxable income, highest tax savings and lowest inventory values. LIFO reserve, defined as the excess of current cost (replacement cost) of inventory over LIFO value, is expected to be positive when inventory is experiencing increasing prices. All tables are generated using Microsoft Word.

Table 1. LIFO Reserve (2008-2015) in Millions in Ranks of 2015 Amounts

\begin{tabular}{lllllllll}
\hline Company & 2008 & 2009 & 2010 & 2011 & 2012 & 2013 & 2014 & 2015 \\
\hline EXXON MOBIL CORP & 10000 & 17100 & 21300 & 25600 & 21300 & 21200 & 10600 & 4500 \\
CHEVRON CORP & 9368 & 5491 & 6975 & 9025 & 9292 & 9150 & 8135 & 3745 \\
VALERO ENERGY CORP & 686 & 4500 & 6100 & 6800 & 6700 & 6900 & 857 & 790 \\
IMPERIAL OIL LTD & 812 & 1509 & 1857 & 2160 & 1769 & 1680 & 739 & 309 \\
WESTERN REFINING INC & 26 & 126 & 174 & 214 & 148 & 194 & 28 & 198 \\
CALUMET SPECIALTY PRODS & $-L P 28$ & 30 & 56 & 88 & 38 & 32 & 19 & 41 \\
UNITED REFINING CO & 153 & 5 & 50 & 92 & 78 & 109 & 110 & 6 \\
CONOCOPHILLIPS & 1959 & 5627 & 6794 & 8400 & 200 & 160 & 6 & 6 \\
ALON USA ENERGY INC & 4 & 100 & 115 & 93 & 58 & 61 & 8 & 1 \\
HESS CORP & 500 & 815 & 995 & 1276 & 1123 & 339 & 0 & 0 \\
HOLLYFRONTIER CORP & 33 & 207 & 284 & 378 & 134 & 273 & 0 & 0 \\
MURPHY OIL CORP & 202 & 551 & 735 & 580 & 571 & 269 & 0 & 0 \\
\hline MEAN & 1981 & 3005 & 3786 & 4559 & 3451 & 3364 & 1709 & 800 \\
\hline
\end{tabular}


Table 1 presents the total dollar amount of LIFO reserve for each of the 12 oil companies. The Exxon Mobile has the greatest LIFO reserve in all the eight years and hence the largest potential dollar amount accounting distortion in inventory. Calumet Specialty Product has lowest LIFO reserve in most of the eight years. Three companies report zero LIFO reserve in 2014 and 2015. The average LIFO reserve for all the 12 firms are also provided for all of the eight years. We can clearly observe that LIFO reserve increases every year from 2008 through 2011 to 4559 million and experiences a decreasing trend from 2012 through 2015 to 800 million. A very significant reduction of LIFO reserve is observed across board for all the 12 oil companies in 2014 and 2015 with a decrease of about 50\% each year.

Table 2. LIFO Reserve as A Percentage of Inventory (2008- 2015) in Ranks of 2015 Percentage

\begin{tabular}{lllllllll}
\hline Company & 2008 & 2009 & 2010 & 2011 & 2012 & 2013 & 2014 & 2015 \\
\hline CHEVRON CORP & 137 & 99 & 127 & 163 & 151 & 143 & 125 & 59 \\
IMPERIAL OIL LTD & 148 & 280 & 353 & 288 & 213 & 173 & 76 & 36 \\
WESTERN REFINING INC & 6 & 28 & 43 & 49 & 34 & 32 & 4 & 33 \\
EXXON MOBIL CORP & 86 & 148 & 164 & 170 & 146 & 131 & 64 & 28 \\
VALERO ENERGY CORP & 15 & 93 & 123 & 121 & 112 & 120 & 13 & 13 \\
CALUMET SPE. PRODS -LP & 23 & 22 & 38 & 18 & 7 & 6 & 4 & 11 \\
UNITED REFINING CO & 162 & 2 & 24 & 54 & 50 & 83 & 72 & 3 \\
ALON USA ENERGY INC & 2 & 47 & 82 & 63 & 32 & 48 & 7 & 1 \\
CONOCOPHILLIPS & 38 & 114 & 131 & 181 & 21 & 13 & 0 & 1 \\
HESS CORP & 38 & 57 & 69 & 90 & 89 & 36 & 0 & 0 \\
HOLLYFRONTIER CORP & 26 & 68 & 71 & 34 & 10 & 20 & 0 & 0 \\
MURPHY OIL CORP & 34 & 75 & 96 & 87 & 76 & 91 & 0 & 0 \\
\hline MEAN & 75 & 117 & 139 & 152 & 125 & 117 & 58 & 29 \\
\hline
\end{tabular}

Table 2 reports the results of the LIFO reserve as a percentage of inventory. LIFO reserve as a percentage of inventory is calculated by dividing the dollar amount of the LIFO reserve to the dollar amount of inventory. LIFO reserve as a percentage of inventory indicates the level of accounting inventory distortion. Imperial Oil has the greatest LIFO reserve to inventory percentage in most of the eight years and therefore the greatest accounting inventory distortion. Western Refining has the smallest LIFO reserve to inventory percentage in most of the eight years and therefore the least accounting inventory distortion. The average percentage for all the 12 oil companies are also reported in the table. A close examination reveals that the average LIFO reserve to inventory percentage steadily increases from $75 \%$ to $152 \%$ for 2008 through 2011 . The average LIFO reserve to inventory percentage starts to get lower each year from 2012 with the fasted decline observed in the year 2014 and 2015. Similar to observations from Table 1, the accounting inventory distortion starts to decline more and more in recent years.

Table 3. LIFO Reserve as A Percentage of Net Sales (2008-2015) in Ranks of 2015 Percentage

\begin{tabular}{lllllllll}
\hline Company & 2008 & 2009 & 2010 & 2011 & 2012 & 2013 & 2014 & 2015 \\
\hline CHEVRON CORP & 3.7 & 3.4 & 3.7 & 3.8 & 4.2 & 4.3 & 4.2 & 3.1 \\
WESTERN REFINING INC & 0.2 & 1.9 & 2.2 & 2.4 & 1.6 & 1.9 & 0.2 & 2.0 \\
EXXON MOBIL CORP & 2.4 & 6.2 & 6.2 & 5.9 & 5.1 & 5.4 & 2.9 & 1.9 \\
IMPERIAL OIL LTD & 3.3 & 7.9 & 7.9 & 7.5 & 5.9 & 5.7 & 2.5 & 1.7 \\
CALUMET SPE. PRODS -LP & 1.1 & 1.6 & 2.5 & 2.8 & 0.8 & 0.6 & 0.3 & 1.0 \\
VALERO ENERGY CORP & 0.6 & 7.1 & 7.5 & 5.4 & 4.8 & 5.0 & 0.7 & 1.0 \\
UNITED REFINING CO & 4.8 & 0.2 & 1.9 & 2.9 & 2.1 & 3.0 & 3.2 & 0.2 \\
CONOCOPHILLIPS & 0.9 & 4.1 & 3.9 & 12.8 & 0.3 & 0.3 & 0.0 & 0.0 \\
ALON USA ENERGY INC & 0.1 & 2.6 & 2.9 & 1.3 & 0.7 & 0.9 & 0.1 & 0.0 \\
HESS CORP & 1.2 & 2.8 & 2.9 & 3.3 & 3.0 & 1.5 & 0.0 & 0.0 \\
HOLLYFRONTIER CORP & 0.6 & 4.3 & 3.4 & 2.4 & 0.7 & 1.4 & 0.0 & 0.0 \\
MURPHY OIL CORP & 0.7 & 2.9 & 3.6 & 2.1 & 2.0 & 5.1 & 0.0 & 0.0 \\
\hline MEAN & 2.1 & 5.0 & 5.1 & 5.5 & 4.2 & 4.5 & 2.4 & 1.8 \\
\hline
\end{tabular}


Table 3 shows the results of LIFO reserve as a percentage of net sales. LIFO reserve as a percentage of net sales is calculated as the dollar amount of the LIFO reserve divided by the dollar amount of net sales, which again reveals level of accounting distortion. Chevron is shown to have the greatest percentage of LIFO reserve to net sales in most of eight years. On average, LIFO reserve as a percentage of net sales increases from $2.1 \%$ in 2008 to a peak of 5.5\% in 2011. After that, it steadily decreases to a percentage of $1.8 \%$ in 2015. Again, a huge decline in the average percentage is observed in 2014. Accounting distortion as represented by LIFO reserve as a percentage of net sales become less severe in recent years.

Table 4. LIFO Inventory Distortion Percentage (2008- 2015) in Ranks of 2015 Percentage

\begin{tabular}{lllllllll}
\hline Company & 2008 & 2009 & 2010 & 2011 & 2012 & 2013 & 2014 & 2015 \\
\hline CHEVRON CORP & 136.7 & 99.3 & 127.0 & 162.8 & 151.2 & 143.4 & 125.1 & 59.1 \\
IMPERIAL OIL LTD & 147.7 & 280.0 & 352.8 & 288.2 & 213.0 & 173.5 & 76.4 & 35.9 \\
WESTERN REFINING INC & 5.6 & 27.7 & 42.8 & 49.4 & 33.9 & 32.1 & 4.2 & 33.0 \\
EXXON MOBIL CORP & 85.9 & 148.0 & 164.1 & 170.4 & 146.5 & 131.4 & 63.6 & 27.7 \\
VALERO ENERGY CORP & 14.8 & 92.5 & 123.3 & 120.9 & 112.2 & 119.8 & 12.9 & 13.4 \\
CALUMET SPE. PRODS -LP & 23.2 & 22.2 & 38.0 & 17.6 & 6.9 & 5.7 & 3.7 & 10.7 \\
UNITED REFINING CO & 161.9 & 2.2 & 24.3 & 53.6 & 49.8 & 83.2 & 72.4 & 3.0 \\
ALON USA ENERGY INC & 1.7 & 46.7 & 81.6 & 63.4 & 31.7 & 47.5 & 6.8 & 0.8 \\
CONOCOPHILLIPS & 38.4 & 113.9 & 130.7 & 181.4 & 20.7 & 13.4 & 0.5 & 0.5 \\
HESS CORP & 38.2 & 56.7 & 68.5 & 89.7 & 89.2 & 35.5 & 0.0 & 0.0 \\
HOLLYFRONTIER CORP & 26.2 & 68.2 & 70.9 & 33.9 & 10.2 & 20.2 & 0.0 & 0.0 \\
MURPHY OIL CORP & 33.5 & 75.1 & 96.4 & 87.0 & 75.9 & 91.3 & 0.0 & 0.0 \\
\hline Mean & 74.9 & 116.5 & 139.1 & 151.9 & 125.0 & 117.1 & 58.0 & 28.9 \\
\hline
\end{tabular}

Table 4 to 9 gives us more insights into liquidity measures. Table 4 presents the LIFO inventory distortion percentage. LIFO inventory distortion percentage is to compare the inventory valued under LIFO with inventory valued using current cost and measures the balance sheet accounting distortion of LIFO. Imperial Oil is shown to have the greatest distortion in most years, while a significant reduction in the distortion is also observed in 2014 and 2015. On average, we document that LIFO has distorted inventory by $74.9 \%$ in 2008 and by $151.9 \%$ in 2011 . However, the distortion reverses to a decreasing trend starting from 2012 with a percentage of $28.9 \%$ in 2015. Consistent with prior observations, LIFO inventory distortion significantly eases in 2014 and 2015.

Table 5. Inventory Turnover Distortion Percentage (2008- 2015) in Ranks of 2015 Percentage

\begin{tabular}{lllllllll}
\hline Company & 2008 & 2009 & 2010 & 2011 & 2012 & 2013 & 2014 & 2015 \\
\hline CHEVRON CORP & -59.3 & -56.5 & -55.3 & -61.2 & -63.2 & -61.8 & -59.6 & -50.1 \\
IMPERIAL OIL LTD & -72.5 & -71.2 & -78.3 & -78.2 & -73.5 & -68.2 & -56.9 & -37.8 \\
EXXON MOBIL CORP & -62.1 & -57.5 & -64.1 & -65.4 & -63.8 & -60.9 & -51.0 & -33.0 \\
UNITED REFINING CO & -48.1 & -32.5 & -12.9 & -29.6 & -35.7 & -41.5 & -45.6 & -24.7 \\
WESTERN REFINING INC & -20.9 & -15.9 & -27.5 & -33.4 & -30.6 & -2630.8 & -1494.4 & -17.1 \\
VALERO ENERGY CORP & -44.2 & -40.0 & -55.7 & -57.5 & -56.1 & -56.1 & -38.9 & -12.6 \\
CALUMET SPE. PRODS -LP & -38.2 & -20.0 & -25.5 & -20.8 & -11.5 & -6.5 & -4.9 & -7.4 \\
ALON USA ENERGY INC & -21.0 & -21.1 & -39.6 & -42.8 & -31.9 & -28.3 & -21.8 & -3.9 \\
CONOCOPHILLIPS & -48.6 & -45.8 & -57.1 & -68.8 & -60.8 & -14.7 & -6.2 & -0.5 \\
HESS CORP & -38.4 & -34.8 & -40.9 & -46.6 & -49.3 & -41.3 & -18.6 & 0.0 \\
HOLLYFRONTIER CORP & -46.9 & -38.8 & -43.2 & -32.4 & -18.0 & -14.5 & -10.3 & 0.0 \\
MURPHY OIL CORP & -43.1 & -38.2 & -48.5 & -49.2 & -46.1 & -55.5 & -33.3 & 0.0 \\
\hline Mean & -47.6 & -42.3 & -50.1 & -51.6 & -47.5 & -40.2 & -31.4 & -15.2 \\
\hline
\end{tabular}


Table 5 reports the accounting distortion in inventory turnover ratio. It is calculated as the percentage difference between the adjusted inventory turnover ratio and reported inventory turnover ratio. Imperial Oil has the greatest accounting distortion in inventory turnover ratio in most of the eight years. The average inventory turnover distortions increases steadily from $47.6 \%$ in 20018 to $51.6 \%$ in 2011 . The inventory turnover distortions starts to decline from 2012 to a level of $15.2 \%$ in 2015. Again, a significant reduction in inventory turnover distortion can be observed in 2014 and 2015.

Table 6. Gross Profit Distortion Percentage (2008- 2015) in Ranks of 2015 Percentage

\begin{tabular}{lllllllll}
\hline Company & 2008 & 2009 & 2010 & 2011 & 2012 & 2013 & 2014 & 2015 \\
\hline CHEVRON CORP & 18.2 & 17.0 & 15.7 & 15.8 & 16.9 & 19.2 & 18.9 & 14.8 \\
WESTERN REFINING INC & 6.1 & 34.3 & 50.8 & 19.9 & 16.1 & 23.6 & 1.8 & 13.6 \\
EXXON MOBIL CORP & 10.4 & 31.1 & 29.7 & 29.5 & 26.1 & 29.3 & 16.1 & 10.2 \\
IMPERIAL OIL LTD & 14.5 & 38.1 & 38.5 & 35.5 & 26.0 & 30.5 & 13.1 & 9.6 \\
VALERO ENERGY CORP & 9.6 & 201.1 & 159.9 & 117.5 & 97.3 & 116.1 & 11.0 & 9.4 \\
CALUMET SPE. PRODS -LP & 8.8 & 12.8 & 21.6 & 26.0 & 6.3 & 6.1 & 2.8 & 5.5 \\
UNITED REFINING CO & 140.8 & 2.0 & 53.2 & 34.9 & 13.8 & 21.0 & 32.4 & 1.7 \\
ALON USA ENERGY INC & 1.9 & 68.2 & 148.7 & 22.5 & 9.9 & 14.1 & 1.7 & 0.2 \\
CONOCOPHILLIPS & 4.9 & 26.7 & 25.9 & 33.6 & 0.9 & 0.7 & 0.0 & 0.1 \\
HESS CORP & 5.3 & 12.2 & 12.0 & 13.9 & 11.4 & 4.0 & 0.0 & 0.0 \\
HOLLYFRONTIER CORP & 10.3 & 86.5 & 62.9 & 18.8 & 4.1 & 16.0 & 0.0 & 0.0 \\
MURPHY OIL CORP & 5.0 & 20.3 & 23.0 & 15.4 & 15.1 & 6.8 & 0.0 & 0.0 \\
\hline \multicolumn{1}{c}{ MEAN } & 11.1 & 28.8 & 27.7 & 27.7 & 21.6 & 23.8 & 13.0 & 9.8
\end{tabular}

Table 6 presents gross profit distortion. Gross profit distortion is the percentage difference between the adjusted gross profit and the reported gross profit. Imperial Oil is found to have the greatest gross profit distortion in most of the eight years. On average, the gross profit distortion is $11.1 \%$ in 2008 and increases to $28.8 \%$ in 2009 and remains steady through 2011. Starting from 2012, the gross profit distortion starts to decline to a level of $9.8 \%$ in 2015 . We again observe the biggest decline occurs in 2014.

Table 7. Working Capital Distortion Percentage (2008- 2015) in Ranks of 2015 Percentage

\begin{tabular}{lllllllll}
\hline Company & 2008 & 2009 & 2010 & 2011 & 2012 & 2013 & 2014 & 2015 \\
\hline CHEVRON CORP & 210.7 & 49.9 & 35.2 & 46.0 & 43.2 & 53.1 & 78.9 & 42.2 \\
WESTERN REFINING INC & 8.1 & 40.6 & 63.6 & 39.2 & 26.5 & 43.2 & 3.8 & 17.8 \\
VALERO ENERGY CORP & 21.2 & 144.0 & 128.9 & 208.3 & 147.9 & 112.1 & 12.9 & 10.4 \\
UNITED REFINING CO & 74.1 & 2.3 & 30.6 & 49.3 & 24.7 & 29.1 & 37.5 & 1.9 \\
ALON USA ENERGY INC & 1.6 & 119.3 & 11623.5 & 93.9 & 66.7 & 100.6 & 6.6 & 1.1 \\
HESS CORP & -125.6 & 71.7 & 85.3 & 533.9 & 22460.0 & 16.6 & 0.0 & 0.0 \\
HOLLYFRONTIER CORP & 48.2 & 80.3 & 90.6 & 18.6 & 4.8 & 12.3 & 0.0 & 0.0 \\
MURPHY OIL CORP & 21.1 & 46.2 & 118.6 & 93.2 & 81.7 & 94.4 & 0.0 & 0.0 \\
CONOCOPHILLIPS & -209.1 & -222.6 & 93.8 & 390.7 & 3.1 & 4.1 & 0.2 & -1.3 \\
IMPERIAL OIL LTD & 201.2 & -600.4 & -178.9 & -253.6 & -97.2 & -63.8 & -35.5 & -24.8 \\
EXXON MOBIL CORP & 43.2 & 538.8 & -583.7 & -563.6 & 6635.5 & -170.7 & -90.4 & -39.6 \\
CALUMET SPECIALTY & & & & & & & & \\
PRODS -LP & 16.4 & 19.0 & 85.4 & 22.5 & 10.7 & 6.8 & 5.2 & -233.0 \\
\hline Mean & 74.5 & 201.5 & 152.9 & 230.2 & 115.3 & 222.6 & 175.2 & 135.6 \\
\hline
\end{tabular}


Table 7 reports the working capital distortion. The working capital distortion is calculated as the percentage difference between the adjusted working capital and reported working capital. Chevron Corp is said to have the greatest working capital distortion in 2008, which Exxon Mobile has the greatest working capital distortion in 2009, 2014 and 2015. The average working capital distortion is about $74.5 \%$ in 2008 , jumps to $201.5 \%$ in 2009 , and reduces to $152.9 \%$ in 2010 , jumped again to $230.2 \%$ in 2011 . The distortion is almost halved in 2012 to $115.3 \%$, but jumps back up to $222.6 \%$ in 2013 and slowly reduced to $175.2 \%$ in 2014 and $135.6 \%$ in 2015.

Table 8. Current Ratio Distortion Percentage (2008- 2015) in Ranks of 2015 Percentage

\begin{tabular}{llllccccc}
\hline Company & 2008 & 2009 & 2010 & 2011 & 2012 & 2013 & 2014 & 2015 \\
\hline IMPERIAL OIL LTD & 21.4 & 45.0 & 52.5 & 43.2 & 43.0 & 41.7 & 24.0 & 11.6 \\
CHEVRON CORP & 25.7 & 14.8 & 14.3 & 17.0 & 16.7 & 18.2 & 19.3 & 10.6 \\
EXXON MOBIL CORP & 13.8 & 31.0 & 36.1 & 35.1 & 33.0 & 35.7 & 20.0 & 10.6 \\
WESTERN REFINING INC & 3.1 & 13.4 & 21.0 & 17.7 & 11.5 & 10.5 & 1.6 & 10.3 \\
CALUMET SPE. PRODS -LP & 9.0 & 10.2 & 18.1 & 11.3 & 4.6 & 3.3 & 2.1 & 6.7 \\
VALERO ENERGY CORP & 7.3 & 41.2 & 45.1 & 42.6 & 40.7 & 35.8 & 5.2 & 5.3 \\
UNITED REFINING CO & 49.7 & 1.4 & 14.1 & 25.7 & 17.9 & 22.8 & 25.5 & 1.4 \\
ALON USA ENERGY INC & 0.6 & 23.1 & 29.2 & 15.3 & 11.4 & 10.2 & 1.5 & 0.2 \\
CONOCOPHILLIPS & 9.4 & 26.6 & 19.6 & 27.8 & 0.8 & 0.8 & 0.0 & 0.1 \\
HESS CORP & 6.8 & 10.2 & 11.3 & 15.3 & 13.4 & 3.9 & 0.0 & 0.0 \\
HOLLYFRONTIER CORP & 6.2 & 16.1 & 16.7 & 8.1 & 3.0 & 7.0 & 0.0 & 0.0 \\
MURPHY OIL CORP & 7.1 & 16.3 & 20.7 & 16.8 & 13.9 & 7.7 & 0.0 & 0.0 \\
\hline \multicolumn{1}{c}{ MEAN } & 16.1 & 18.0 & 23.4 & 21.2 & 15.1 & 15.6 & 8.4 & 4.2 \\
\hline
\end{tabular}

Table 8 presents the current ratio distortion. The current ratio distortion is calculated as the percentage difference between the adjusted current ratio and reported current ratio. Imperial Oil is shown to have the greatest current ratio distortion in most of the eight years. The average current ratio distortion is $16.1 \%$ in 2008 and gradually increases to $23.4 \%$ in 2010. After that the current ratio distortion starts to show a declining pattern to reach the lowest level of $4.2 \%$ in 2015. Compared to other distortion measures, current ratio is the least distorted by using LIFO.

\section{Discussion}

There have been no recent studies on the LIFO distortions in the oil industry. Our study filled this gap. We find that the use of LIFO inventory accounting method leads to significant accounting information distortions in inventory turnover, gross profit, working capital, and current ratio for the oil industry. The greatest accounting distortion from using LIFO is in working capital. The inventory turnover ratio is the second greatest distorted measure. We also document a very clear pattern of increasing accounting information distortion from 2008 to 2011 . However, the distortion starts to decline significantly in recent years from 2012 to 2015. The dramatic decline in oil prices in recent years appears to be the main driver of the decreasing distortions. In particular, the oil industry experienced challenging times in 2015. Oil prices started to decline sharply in the fourth quarter of 2014 and reached the low $\$ 50$ s per barrel in January 2015. The price increased to around \$60 per barrel in May and June but reached at $\$ 37$ per barrel at the end of 2015 .

\section{Conclusion}

The reversal in accounting distortion trend from LIFO usage is worth noting. Each of the Obama administration's budgets proposals proposed the elimination of LIFO for inventories. We believe the findings of our research have significant implications for the policy makers. In addition, a full adoption of IFRS, which prohibits LIFO, is unlikely in the near future. Non-public companies who are not under the jurisdiction of the SEC may still continue to use LIFO after the adoption of IFRS. The limitation of this paper is the narrow focus on the impact of LIFO in the largest oil companies. The observations derived might not be applicable to smaller oil firms and other industries. Future research might focus on the impact of LIFO on these firms and industries. 


\section{References}

Coffee, D., R. Roig, R. Lirely, \& P. Little (2009). The materiality of LIFO accounting distortion on liquidity measurements. Journal of Finance and Accountancy (January), 35-46.

Guenther, D. A. \& Sansing, R. C. (2012). Unintended consequences of LIFO repeal: the case of the oil industry. The Accounting Review, 87(5), 1589-1602. https://doi.org/10.2308/accr-50194

Harris, P. \& Stahlin, W. (2014). The theoretical defenses of the last in first out inventory methods. Journal of Business \& Economics Research, 12(1), 43-46. https://doi.org/10.19030/jber.v12i1.8376

Harris, P., Stahlin, W. \& Shubita, M. F. (2014). US GAAP conversion to IFRS: a case study of the cash flow statement. Journal of Business Case Studies, 10(1), 15-20. https://doi.org/10.19030/jbcs.v10i1.8325

Hughes, P. A \& Nucci, L. (2015). Drop in oil prices causes U.S. LIFO reserves significant drop in tax liability from U.S. GAAP to IFRS transition for oil industry- Who Cares? Journal of Business \& Economic Policy, 2(4), 12-17.

Houmes, R. \& Chira, I. (2015). The valuation effect of LIFO's repeal on high pricing power firms. Review of Accounting \& Finance, 14(3), 306-323. https://doi.org/10.1108/RAF-06-2014-0062

Kostolansky, J. (2009). The impact of LIFO in the Fortune 500 in 2007. Journal of Applied Business Research, 25(5), 11-20. https://doi.org/10.19030/jabr.v25i5.1002

Kostolansky, J. \& Polnaszek, E. (2013). New perspectives on the use of LIFO and firm size. Journal of Applied Business Research, 29(5), 1501-1508. https://doi.org/10.19030/jabr.v29i5.8031

Leone, M. (2010). Sucking the LIFO out of inventory: The government sees billions of dollars in potential tax revenue sitting on the shelves of company warehouses. CFO Magazine (July/August), 27-29.

Lessard, S. C. (2007). Giving life to LIFO: adoption of the LIFO method of inventory valuation by the income tax code. The Tax Lawyer, 60(3), 781-806.

Li, J. \& Sun, M. Y. (2014). LIFO and accounting distortion - the case of the oil industry. Journal of Accounting and Finance, 14(5), 86-96.

Li, J. \& Sun, M. Y. (2016). LIFO distortions in the manufacturing industry. Accounting and Finance Research, 5(1), 191-201. https://doi.org/10.5430/afr.v5n1p191

Lirely, R., Coffee, D., Roig,R., \& Swanger S. (2010). LIFO accounting and liquidity measurements in the energy industry. Oil, Gas, and Energy Quarterly (No. 3), 393-406.

Lundeen, A. (2016). Proposed tax changes in President Obama's fiscal year 2016 budget. Tax Foundation (February 11). http://taxfoundation.org.

Moreland, K. A. (2007). International financial reporting-inventory costing at Exxon and BP. Issues in Accounting Education, 22(4), 549-561. https://doi.org/10.2308/iace.2007.22.4.549

Murdoch, B., Dehning, B., \& Krause, P. (2013). Further evidence on the ability of FIFO and LIFO earnings to predict operating cash flows: an industry specific analysis. The Journal of Applied Business Research, 29(4), 1231-1241. https://doi.org/10.19030/jabr.v29i4.7929

Pomerleau, K. (2016). The Tax treatment of inventories and the economic and budgetary Impact of LIFO repeal. Tax Foundation Fiscal Fact, (February 20, No. 501).

Reeve, J. M. \& Stanga K. G. (1987). Balance sheet impact of using LIFO: an empirical study. Accounting Horizons (September), 9-15.

Reineking, C., Chamberlain, D.H., Rudolph, H. \& Smith M. (2013). An examination of inventory costing convergence under Generally Accepted Accounting Principles and International Financial Reporting Standards. Journal of International Business Research, 12(2), 17-32.

Thomas, J. \& Zhang, F. (2014). Valuation of tax expense. Review of Accounting Studies, 19(4), 436-1467. https://doi.org/10.19030/jabr.v29i4.7929 